\title{
PENGARUH PERBANDINGAN TEPUNG TERIGU DENGAN BUBUR LABU KUNING (Cucurbita moschata) dan PENAMBAHAN NATRIUM KARBONAT $\left(\mathrm{Na}_{2} \mathrm{CO}_{3}\right)$ TERHADAP MIE BASAH YANG DI HASILKAN
}

Oleh :

MISBAR

202091010008

SKRIPSI

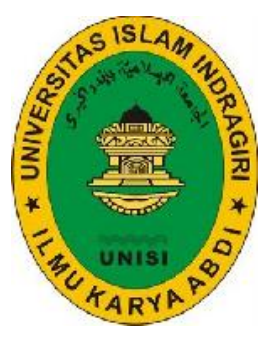

PROGRAM STUDI TEKNOLOGI PANGAN

FAKULTAS PERTANIAN

UNIVERSITAS ISLAM INDRAGIRI

2013 
PERNYATAAN

\title{
PENGARUH PERBANDINGAN TEPUNG TERIGU DENGAN BUBUR LABU KUNING (Cucurbita moschata) dan PENAMBAHAN NATRIUM KARBONAT $\left(\mathrm{Na}_{2} \mathrm{CO}_{3}\right)$ TERHADAP MIE BASAH YANG DI HASILKAN
}

\begin{abstract}
KARYA ILMIAH
Saya mengakui bahwa tugas akhir ini adalah hasil kerja saya sendiri. Sumber imformasi yang berasal atau dikutip dari karya yang diterbitkan maupun tidak diterbitkan dari penulis lain telah disebutkan dalam teks dan dicantumkan dalam Daftar Pustaka dibagian akhir skripsi ini.
\end{abstract}

Tembilahan, 22 Maret 2013

MISBAR

NIM. 202091010008 


\title{
PENGARUH PERBANDINGAN TEPUNG TERIGU DENGAN BUBUR LABU KUNING (Cucurbita moschata) dan PENAMBAHAN NATRIUM KARBONAT $\left(\mathrm{Na}_{2} \mathrm{CO}_{3}\right)$ TERHADAP MIE BASAH YANG DI HASILKAN
}

\begin{abstract}
ABTRAK
Penelitian ini bertujuan untuk mengetahui pengaruh perbandingan tepung terigu dengan bubur labu kuning dan penambahan natrium karbonat $\left(\mathrm{Na}_{2} \mathrm{CO}_{3}\right)$ terhadap mie basah yang dihasilkan. Penelitian dilakukan dengan menggunakan Rancangan Acak Lengkap (RAL) faktorial dengan dua faktor, yang terdiri dari : Faktor I (A) : perbandingan tepung terigu dengan bubur labu kuning, yang terdiri dari beberapa taraf yaitu : $\mathrm{A}_{1}=$ Tanpa penambahan bubur labu kuning, $\mathrm{A}_{2}=$ Tepung terigu $85 \%$ : bubur labu kuning $15 \%, \mathrm{~A}_{3}=$ Tepung terigu $70 \%$ : bubur labu kuning $30 \%$ dan $\mathrm{A}_{4}=$ Tepung terigu $55 \%$ : bubur labu kuning $45 \%$. Faktor II (B) : Jumlah natrium karbonat, $B_{1}=0,10 \mathrm{~g} / 100 \mathrm{ml}, B_{2}=0,15 \mathrm{~g} / 100 \mathrm{ml}$ dan $B_{3}=0,20$ $\mathrm{g} / 100 \mathrm{ml}$.

Analisa dilakukan untuk menentukan kadar air, kadar protein, kadar abu, organoleptik warna, organoleptik aroma dan organoleptik tekstur. Untuk kualitas yang terbaik, semakin banyak tepung terigu dan semakin tinggi natrium karbonat (A1B3) dengan jumlah kadar air $70.83 \%$, kadar protein $14.97 \%$, kadar abu 1.50 $\%$, warna 3.06 , aroma 3.02 dan tekstur 3.06.
\end{abstract}

Kata kunci : Tepung terigu, labu kuning dan natrium karbonat. 


\section{DAFTAR ISI}

Halaman

\section{KATA PENGANTAR}

DAFTAR ISI .......................................................................... i

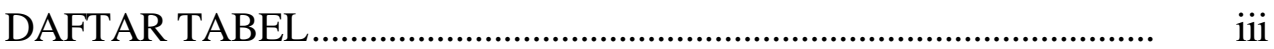

DAFTAR LAMPIRAN ….............................................................. iv

I. PENDAHULUAN

1.1. Latar Belakang .................................................................. 1

1.2. Rumusan Masalah.................................................................. 3

1.3. Tujuan Penelitian ...........................................................................

1.4. Manfaat Penelitian .................................................................... 4

1.5. Hipotesa Penelitian ................................................................... 4

II. TINJAUAN PUSTAKA

2.1. Labu kuning dan Komposisinya ........................................ 5

2.2. Manfaat Labu kuning........................................................... 6

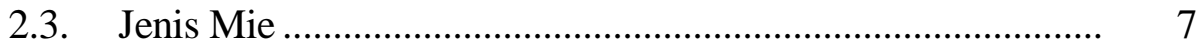

2.4.1 Mie Mentah............................................................... 7

2.4.2 Mie Basah ............................................................. 7

2.4.4 Mie Kering ............................................................. 7

2.4.4 Mie Instan .............................................................. 8

2.5 Standard Mutu Mie Basah .................................................. 9

2.6 Bahan-Bahan Pembuat Mie Basah Dari Labu kuning ........... 10

2.6.1 Tepung Terigu........................................................... 10

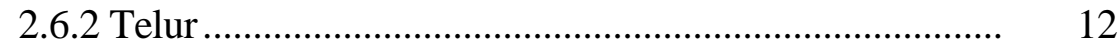

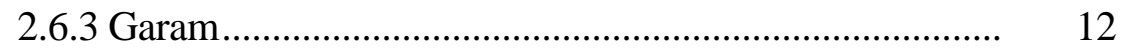

2.6.4 Air ........................................................................... 13

2.6.5 Natrium Karbonat ........................................................ 13

III. METODOLOGI PENELITIAN

3.1.Tempat dan Waktu................................................................... 16

3.2. Bahan dan Alat ................................................................ 16

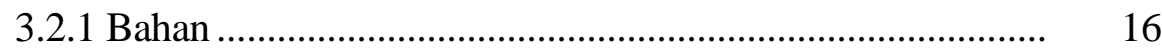

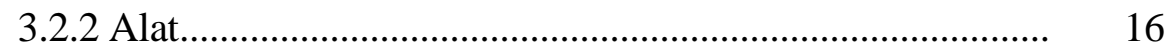

3.3.Metoda Penelitian .................................................................. 16

3.4.Pelaksanaan Penelitian ................................................................... 18

3.4.1. Pembutan Bubur Labu kuning........................................ 18

3.4.2. Pembuatan Mie dengan Penambahan Labu kuning......... 19 


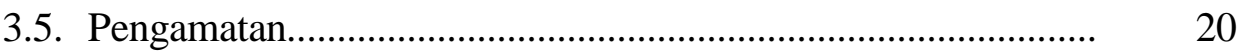

3.5.1. Kadar Air .................................................................. 20

3.5.2. Kadar Protein ............................................................... 21

3.5.3. Kadar Abu ................................................................ 22

3.5.4. Uji Organoleptik....................................................... 22

IV. HASIL DAN PEMBAHASAN

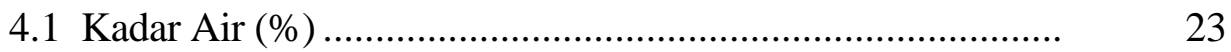

4.2 Kadar Protein ............................................................ 24

4.3 Kadar Abu ..................................................................... $\quad 26$

4.4 Uji Organoleptik ......................................................... 28

4.4.1 Organoleptik Warna ............................................... $\quad 28$

4.4.2 Organoleptik Aroma ................................................ $\quad 30$

4.4.3Organoleptik Tekstur ................................................. 31

V. KESIMPULAN DAN SARAN

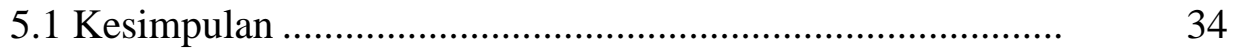

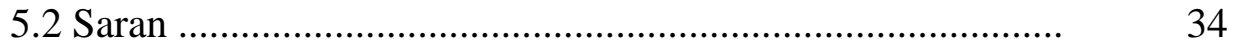

DAFTAR PUSTAKA

LAMPIRAN 
DAFTAR TABEL

1. Komposisi Zat Gizi Labu Kuning Dalam 100 gr Bahan ............. 6

2. Standar Mutu Mie Basah ............................................................ $\quad 10$

3. Komposisi Kimia Tepung Terigu Dalam 100 gr Bahan............... 11

4. Batas maksimum penggunan BTP pada formula bayi menurut SNI dan Standar Codex.

5. Kombinasi Perlakuan

6. Pengaruh Interaksi Jumlah Bubur Labu kuning dan Jumlah Natrium Karbonat terhadap Kadar Air (\%).

7. Pengaruh Interaksi Jumlah Bubur Labu kuning dan Jumlah Natrium Karbonat terhadap Kadar Protein (\%)

8. Pengaruh Interaksi Jumlah Bubur Labu kuning dan Jumlah Natrium Karbonat terhadap Kadar Abu (\%)

9. Pengaruh Interaksi Jumlah Bubur Labu kuning dan Jumlah Natrium Karbonat terhadap Organoleptik Warna (\%).

10. Pengaruh Interaksi Jumlah Bubur Labu kuning dan Jumlah Natrium Karbonat terhadap Organoleptik Aroma (\%)

11. Pengaruh Interaksi Jumlah Bubur Labu kuning dan Jumlah Natrium Karbonat terhadap Organoleptik Tekstur (\%) 
DAFTAR GAMBAR

1. Grafik Pengaruh Perbandingan Tepung Terigu Dengan Bubur Labu Kuning dan Penambahan Natrium Karbonat terhadap Nilai Sensori Warna, Aroma dan Tekstur. 


\section{DAFTAR LAMPIRAN}

Nomor

Halaman

1. Jadwal Pelaksanaan Penelitian di Laboratorium Teknologi Pangan Fakultas Pertanian Universitas Islam Indragiri.

2. Skema Pembuatan Bubur Labu Kuning

3. Skema Pembuatan Mie Basah Dengan

Penambahan Bubur Labu kuning

4. Uji Skala Hedonik

5. Perhitungan Analisa Statistik Terhadap Kadar Air, Kadar Protein, Kadar Abu, Organoleptik Warna, Organoleptik Aroma dan Tekstur..

6. Dokumentasi 


\section{PENDAHULUAN}

\subsection{Latar Belakang}

Pada saat ini banyak masyarakat mengkonsumsi mie sebagai bahan pangan alternatif pengganti beras, mengingat harga beras yang terus meningkat. Mie dapat juga digunakan sebagai bahan pangan alternatif karena kandungan gizi mie tidak kalah baiknya dengan beras, dimana bahan baku utamanya adalah tepung terigu. Mie juga dikenal hampir diseluruh dunia walaupun nama, bentuk, bahan penyusun dan cara pembuatannya berbeda. Dalam Bahasa Inggris disebut noodle.

Produk mie yang dikenal oleh masyarakat yaitu mie basah, mie mentah (mie ayam), mie kering dan mie instan. Produk mie basah saat ini mengalami perkembangan dengan variasi campuran antara tepung terigu sebagai bahan baku utama dengan bahan-bahan lain seperti umbi-umbian dan sayur-sayuran yang tentu saja dapat meningkatkan kandungan gizi mie tersebut, selain itu juga dapat memperbaiki warna mie basah tanpa penambahan zat pewarna lainnya.

Pemanfaatan umbi-umbian maupun sayur-sayuran di Indonesia sebagai bahan campuran mie basah sangatlah rendah. Hal ini terlihat dari konsumsi masyarakat yang luas terhadap umbi-umbian tetapi hanya untuk diolah dalam bentuk yang sederhana saja seperti direbus, digoreng, dan lain sebagainya. Salah satu sayuran yang hanya kebanyakan diolah dalam bentuk rebusan seperti labu kuning.

Labu kuning merupakan salah satu jenis tanaman yang sudah lama dikenal dan banyak digunakan oleh masyarakat dalam olahan pangan tradisional namun 
belum banyak digunakan sebagai bahan baku industri pangan serta belum banyak diusahakan pengawetannya. Padahal ketersediaan labu kuning di Indonesia relatif tinggi karena dapat tumbuh di mana saja. Data Badan Pusat Statistik tahun 2003 menunjukkan hasil rata-rata produksi labu kuning di Indonesia berkisar 20-21 ton per hektar. Namun tingkat konsumsi labu kuning di Indonesia masih sangat rendah, kurang dari $5 \mathrm{~kg}$ per kapita per tahun. Di lihat dari Lingkup pengolahan labu kuning yang masih terbatas dan sederhana maka perlu dilakukan pengolahan.

Disamping itu labu kuning merupakan bahan pangan yang kaya vitamin A, B, dan C, mineral, serta karbohidrat. Daging buahnya pun mengandung antiokisidan sebagai penangkal berbagai jenis kanker. Sifat labu yang lunak dan mudah dicerna serta mengandung betakaroten (pro vitamin A) cukup tinggi, serta dapat menambah warna menarik dalam olahan pangan.

Labu kuning bisa diolah menjadi bahan subtitusi atau bahan tambah di dalam pembuatan mie basah, selain bisa sebagai subtitusi karena mengandung karbohidrat dan bisa sebagai perbaikan warna pada mie basah karena labu mengandung betakaroten yang cukup tinggi, disamping itu perlu diperhatikan bahwa mie basah mempunyai umur simpan yang singkat sekitar 16 - 20 jam jika disimpan pada suhu ruang, untuk itu perlu alternatif penambahan bahan pengawet seperti natrium karbonat $\left(\mathrm{Na}_{2} \mathrm{CO}_{3}\right)$. Tetapi didalam penggunaan perlu kosentrasi yang tepat menurut SNI dan Standar Codex Penggunaan Natrium Karbonat pada Formula Bayi 0,2\%..

Hasil penelitian Andriani FWB, 2008. "Pengaruh Jumlah Bubur Labu Kuning dan Konsentrasi Kitosan Terhadap Mutu Mie Basah” di peroleh hasil terbaik yaitu 
penambahan bubur labu kuning 10\% dan menggunakan konsentrasi kitosan 0,75\%. Oleh sebab itu, untuk memperoleh umur simpan dari mie dalam penelitian ini telah dilakukan penambahan Natrium Karbonat pada pembuatan mie basah. Dari uraian diatas maka peneliti telah melakukan penelitian dengan judul " Pengaruh Perbandingan Tepung Terigu Dengan Bubur Labu Kuning (Cucurbita moschata) dan Penambahan Natrium Karbonat $\left(\mathrm{Na}_{2} \mathrm{CO}_{3}\right)$ Terhadap Mutu Mie Basah yang Dihasilkan “

\subsection{Perumusan Masalah}

Pemanfaatan umbi-umbian maupun sayur-sayuran di Indonesia sebagai bahan campuran mie basah sangatlah rendah. Labu kuning merupakan salah satu jenis tanaman yang sudah lama dikenal dan banyak digunakan oleh masyarakat dalam olahan pangan tradisional namun belum banyak digunakan sebagai bahan baku industri pangan serta belum banyak diusahakan pengawetannya.

Labu kuning merupakan bahan pangan yang kaya vitamin A, B, dan C, mineral, serta karbohidrat. Daging buahnya pun mengandung antiokisidan sebagai penangkal berbagai jenis kanker. Sementara labu bisa diolah menjadi bahan subtitusi atau bahan tambah di dalam pembuatan mie basah, selain labu mengandung karbohidrat dan memperbaiki warna pada mie basah karena mengandung betakarotin, namun mie basah mempunyai daya simpan yang singkat, untuk itu perlu alternative penambahan bahan pengawet seperti natrium 
karbonat $\left(\mathrm{Na}_{2} \mathrm{CO}_{3}\right)$. Adapun setandar natrium karbonat menurut Codex 0,2\% dalam formula bayi.

Berdasarkan hal ini telah dilakukan penelitian yang berjudul " Pengaruh Perbandingan Tepung Terigu Dengan Bubur Labu Kuning (Cucurbita moschata) dan Penambahan Natrium Karbonat $\left(\mathrm{Na}_{2} \mathrm{CO}_{3}\right)$ Terhadap Mutu Mie Basah yang Dihasilkan “

\subsection{Tujuan Penelitian}

Penelitian ini bertujuan untuk mengetahui pengaruh perbandingan tepung terigu dengan bubur labu kuning dan penambahan natrium karbonat $\left(\mathrm{Na}_{2} \mathrm{CO}_{3}\right)$ terhadap mie basah yang dihasilkan.

\subsection{Manfaat Penelitian}

1. Sebagai sumber informasi dalam pembuatan mie basah.

2. Mengetahui pengaruh tepung terigu dengan bubur labu kuning dan penambahan natrium karbonat terhadap mie basah yang dihasilkan. 


\section{TINJAUAN PUSTAKA}

\subsection{Labu kuning dan Komposisinya (Cucurbita moschata)}

Labu Kuning termasuk jenis tanaman menjalar dari famili curcubitacea. Labu Kuning dikenal pula dengan nama labu kuning, karena daging buahnya berwarna kuning. Pumpkin (Inggris), labu parang (jawa barat), labu merah dan labu manis. Labu kuning tergolong tanaman semusim sebab setelah selesai berbuah akan mati. Pada daging buah inilah terkandung beberapa vitamin antara lain : vitamin $\mathrm{C}$, vitamin $\mathrm{A}$, dan vitamin $\mathrm{B}$. Pada bagian tengah labu kuning terdapat biji yang diselimuti lendir dan serat. Biji ini berbentuk pipih dengan kedua ujungnya yang meruncing. Bentuk buah labu kuning ini bermacam-macam tergantung dari jenisnya, ada yang berbentuk bokor (bulat pipih, beralur), oval, panjang dan piala. Berat buah labu kuning rata-rata $2-5 \mathrm{~kg} / \mathrm{buah}$, dan ada yang mencapai $30 \mathrm{~kg} / \mathrm{buah}$ untuk labu kuning jenis tertentu. Tekstur daging buah tergantung jenisnya ada yang halus, padat, lunak, dan mumpur (Sudarto, 1993). Labu Kuning sangat sarat dengan kandungan gizi yang cukup tinggi dan lengkap. Kandungan gizi labu kuning yakni : 
Tabel 1. Komposisi Zat Gizi Labu Kuning per 100g Bahan

\begin{tabular}{|l|c|}
\hline \multicolumn{1}{|c|}{ Komposisi } & Jumlah \\
\hline Kalori (Kal) & 29 \\
\hline Protein (g) & 1,1 \\
\hline Lemak (g) & 0,3 \\
\hline Karbohidrat (mg) & 6,6 \\
\hline Kalsium (mg) & 45 \\
\hline Fosfor (mg) & 64 \\
\hline Besi (mg) & 1,4 \\
\hline Nilai Vit. A (SI) & 180 \\
\hline Vit B1 (mg) & 0,08 \\
\hline Vit C (mg) & 52 \\
\hline Air (g) & 91,2 \\
\hline b.d.d.(\%) & 77 \\
\hline
\end{tabular}

Sumber : Departemen Kesehatan R.I., (1996)

\subsection{Manfaat Labu kuning}

Buah labu kuning mempunyai kandungan kalium dan natrium yang tinggi, sedangkan karbohidratnya tergolong rendah. Buah labu ini sangat kaya akan kandungan serat, vitamin, mineral, dan air sehingga banyak pakar gizi dan kesehatan berkomentar kalau labu kuning bermanfaat untuk kesehatan. Tetapi hanya sedikit yang dimamfaatkan manusia sebagai bahan pangan (Wiryo, 2002).

Labu kuning adalah salah satu sumber makanan detoksifikasi yang mempunyai kemampuan untuk mengatur ketidak seimbangan dalam tubuh. Sayuran banyak mengandung betakaroten yang merupakan (prokursor vitamin A). Labu kuning sebagai sumber vitamin A berfungsi untuk membantu proses penglihatan. Vitamin tersebut merupakan bagian yang sangat penting dari penerimaan cahaya mata (Kumalaningsih, 2006).

Selain dimanfaatkan sebagai bahan pangan dan pengobatan, umbi labu kuning juga dapat digunakan untuk keperluan kosmetik, yakni untuk merawat 
kecantikan wajah dan kulit, menyuburkan rambut, dan lain-lain. Karoten dalam umbi labu kuning bermanfaat untuk menjaga kelembaban kulit, dan memperlambat timbulnya kerutan pada wajah, sehingga wajah selalu tampak berseri (Cahyono,2002).

\subsection{Jenis Mie}

Mie dibuat dengan prinsip yang sama, tetapi di pasaran dikenal beberapa jenis mie, seperti mie segar/mentah (raw chinese noodle), mie basah (boiled noodle), mie kering (steam and fried noodle), dan mie instan (instant noodle)

\subsubsection{Mie mentah}

Mie mentah adalah mie yang tidak mengalami proses tambahan setelah pemotongan dan mengandung air sekitar 35\%. Oleh karena itu, mie ini cepat rusak. Penyimpanan dalam refrigerator dapat mempertahankan kesegaran mie ini hingga 50-60 jam. Setelah masa simpan tersebut, warna mie akan menjadi gelap. Mie mentah umumnya dibuat dari terigu yang keras agar mudah penanganannya. Mie mentah ini umumnya digunakan sebagai bahan baku mie ayam

\subsubsection{Mie basah}

Mie basah adalah jenis mie yang mengalami proses perebusan setelah tahap pemotongan dan sebelum dipasarkan. Kadar airnya dapat mencapai 52\% sehingga daya tahan simpannya relatif singkat (40 jam pada suhu kamar). Di Indonesia, mie basah dikenal sebagai mie kuning atau mie bakso.

\subsubsection{Mie kering}

Mie kering adalah mie mentah yang telah dikeringkan hingga kadar airnya 
mencapai 8-10\%. Pengeringan umumnya dilakukan dengan penjemuran di bawah sinar matahari atau dengan oven. Karena bersifat kering maka mie ini mempunyai daya simpan yang relatif panjang dan mudah penanganannya. Mie kering sebelum dipasarkan biasanya ditambahkan telur segar atau tepung telur sehingga mie ini dikenal dengan nama mie telur. Penambahan telur ini merupakan variasi sebab secara umum mie oriental tidak mengandung telur. Di Amerika Serikat, penambahan telur merupakan suatu keharusan karena mie kering harus mengandung air kurang dari 13\% dan padatan telur lebih dari 5,5\%

\subsubsection{Mie instan}

Mie instan atau disebut juga mie kuning adalah jenis mie yang mengalami proses perebusan setelah tahap pemotongan dan sebelum dipasarkan. Kadar air mie basah dapat mencapai 52\% sehingga daya tahan atau keawetannya cukup singkat. Pada suhu kamar mie basah ini hanya bertahan 1012 jam saja, karena setelah itu mie akan berbau asam dan berlendir atau basi (Widyaningsih dan Murtini,2006).

Kandungan air mie dapat dibedakan menjadi mie basah atau segar dan mie kering. Mie basah digolongkan dalam produk "Intermediate moisture food" (makanan semi basah), yaitu suatu makanan yang mempunyai kadar air tidak terlalu tinggi dan juga tidak terlalu rendah antara 15-55\% dengan kisaran Aw antara 0,65-0,85 (Robsons, 1976). Mie yang dibuat tanpa penambahan STPP, $\mathrm{CMC}$, atau gliserin, tingkat kekenyalan (elastis, tidak mudah putus) kurang sehingga agak lengket. Keawetannya pada suhu kamar hanya bertahan 12 jam sudah agak berbau asam dan mulai berlendir (Widyaningsih dan Murtini, 2006). 
Tabel 2. Standar Mutu Mie Basah

\begin{tabular}{|c|c|c|c|}
\hline No. & Kriteria Uji & Satuan & Persyaratan \\
\hline 1 & $\begin{array}{l}\text { Keadaan : } \\
\text { 1.1 Bau } \\
\text { 1.2 Rasa } \\
\text { 1.3 Warna }\end{array}$ & - & $\begin{array}{l}\text { Normal } \\
\text { Normal } \\
\text { Normal }\end{array}$ \\
\hline 2 & Kadar air & $\% \mathrm{~b} / \mathrm{b}$ & $20-35$ \\
\hline 3 & $\begin{array}{l}\text { Kadar abu (dihitung atas } \\
\text { dasar bahan kering), }\end{array}$ & $\% \mathrm{~b} / \mathrm{b}$ & Maks. 3 \\
\hline 4 & $\begin{array}{l}\text { Kadar protein }((\mathrm{N} \times 6.25) \\
\text { dihitung atas dasar bahan } \\
\text { kering) }\end{array}$ & $\% \mathrm{~b} / \mathrm{b}$ & Min. 3 \\
\hline 5 & $\begin{array}{l}\text { Bahan tambahan pangan } \\
\text { 5.1 Boraks dan asam borat } \\
\text { 5.2 Pewarna } \\
\text { 5.3 Formalin }\end{array}$ & - & $\begin{array}{l}\text { Tidak boleh ada } \\
\text { Sesuai SNI-0222-M dan } \\
\text { peraturan MenKes. No. } \\
\text { 722/Men.Kes/Per/IX/88 } \\
\text { Tidak boleh ada }\end{array}$ \\
\hline 6 & $\begin{array}{l}\text { Cemaran logam : } \\
\text { 6.1 Timbal }(\mathrm{Pb}) \\
\text { 6.2 Tembaga }(\mathrm{Cu}) \\
\text { 6.3 Seng }(\mathrm{Zn}) \\
\text { 6.4 Raksa }(\mathrm{Hg})\end{array}$ & $\mathrm{mg} / \mathrm{kg}$ & $\begin{array}{l}\text { Maks. } 1.0 \\
\text { Maks. } 10.0 \\
\text { Maks. } 40.0 \\
\text { Maks. } 0.05\end{array}$ \\
\hline 7 & Arsen (As) & $\mathrm{mg} / \mathrm{kg}$ & Maks. 0.05 \\
\hline 8 & $\begin{array}{l}\text { Cemaran mikroba: } \\
\text { 8.1 Angka lempeng total } \\
\text { 8.2 E. coli } \\
\text { 8.3 Kapang }\end{array}$ & $\begin{array}{l}\text { Koloni/g } \\
\text { APM/g } \\
\text { Koloni/g }\end{array}$ & $\begin{array}{l}\text { Maks. } 1.0 \text { x } 106 \\
\text { Maks. } 10 \\
\text { Maks. } 1.0 \text { x } 104\end{array}$ \\
\hline
\end{tabular}

Sumber : Dewan Standarisasi Nasional (1992)

\subsection{Bahan Pembuat Mie Basah}

\subsubsection{Tepung Terigu}

Tepung terigu yang digunakan sebaiknya yang mengandung glutein 812\%. Terigu ini tergolong medium hard flour di pasaran dikenal sebagai Segitiga Biru atau Gunung Bromo. Gluten adalah protein yang terdapat pada terigu. Gluten bersifat elastis sehingga akan mempengaruhi sifat elastisitas dan tekstur 
mie yang dihasilkan (Widyaningsih dan Murtini, 2006). Tepung terigu merupakan bahan dasar pembuatan mie. Tepung terigu diperoleh dari biji gandum (Triticum vulgare) yang digiling. Keistimewaan terigu diantara serealia lainnya adalah kemampuannya membentuk gluten pada adonan mie menyebabkan mie yang dihasilkan tidak mudah putus pada proses pencetakan dan pemasakan mie. Mutu terigu yang dikehendaki adalah terigu yang memiliki kadar air 14\%, kadar protein 8-12\%, kadar abu 0,25-0,60\% dan gluten basah 24-36\% (Astawan , 2006). Komposisi kimia tepung terigu dalam 100 gr bahan dapat dilihat pada Tabel 3.

Tabel 3. Komposisi Kimia Tepung terigu dalam 100 gr bahan

\begin{tabular}{|l|c|}
\hline Komponen & Jumlah \\
\hline Kalori (Kal) & 86 \\
Protein (g) & 0,6 \\
Lemak (g) & 3,3 \\
Karbohidrat (g) & 14,0 \\
Kalsium (mg) & 14 \\
Fosfor (mg) & 13 \\
Besi (mg) & 0,8 \\
Vitamin A (SI) & 0 \\
Vitamin B1 (mg) & - \\
Vitamin C (mg) & 0 \\
Air (g) & 80,0 \\
b.d.d (\%) & 100 \\
\hline
\end{tabular}

Sumber : Departemen Kesehatan, R.I.,(1996)

Tepung terigu hasil penggilingan harus bersifat mudah tercurah, kering, tidak menggumpal jika ditekan, berwarna putih, bebas dari kulit partikel, tidak berbau asing seperti busuk, berjamur atau tengik, juga bebas dari serangga, jamur, tikus, kotoran dan kontaminasi asing lainnya. Kadar protein mempunyai korelasi yang erat dengan jumlah total glutein, sedangkan kadar abu erat hubungannya dengan kualitas mie (Sunaryo, 1985). 
Protein tepung gandum adalah unik, bila tepung gandum dicampur dengan air dalam perbandingan tertentu, maka protein akan membentuk suatu massa atau adonan koloidal yang plastis yang dapat menahan gas dan akan membentuk suatu struktur spons bila dipanggang., jenis tepung gandum yang berbeda memerlukan jumlah pencampuran (air) yang berbeda (Desrosier, 1988).

\subsubsection{Telur}

Secara umum, penambahan telur dimaksudkan untuk meningkatkan mutu protein mie dan menciptakan adonan yang lebih liat sehingga tidak mudah terputus-putus. Putih telur berfungsi untuk mencegah kekeruhan saos mie waktu pemasakan. Penggunaan putih telur harus secukupnya saja karena pemakaian yang berlebihan akan menurunkan kemampuan mie menyerap air (daya rehidrasi) waktu direbus (Astawan, 2006).

Kuning telur dipakai sebagai pengemulsi karena dalam kuning telur terdapat Lechitin.Selain sebagai pengemulsi, lechitin juga dapat mempercepat hidrasi air pada tepung dan untuk mengembangkan adonan. Penambahan kuning telur juga akan memberikan warna yang seragam (Astawan, 2006).

\subsubsection{Garam}

Garam dapur selain untuk memberi rasa, juga memperkuat tekstur mie, meningkatkan elastisitas dan fleksibilitas mie, serta untuk mengikat air. Garam dapur akan menghambat aktivitas enzim protease dan amilase sehingga mie tidak bersifat lengket dan tidak mengembang secara berlebihan (Astawan, 2006). 
Penggunaan garam 1-2\% akan meningkatkan kekuatan lembaran adonan dan mengurangi kelengketan. Di Jepang, dalam pembuatan mie pada umumnya ditambahkan 2-3\% garam ke dalam adonan mie. Jumlah ini merupakan kontrol terhadap $\alpha$-amilase jika aktivitas rendah (Widyaningsih dan Murtini, 2006).

\subsubsection{Air}

Air berfungsi sebagai media reaksi antara gluten dengan karbohidrat, larutan garam dan membentuk sifat kenyal gluten, air yang digunakan sebaiknya memiliki PH 6-9. Makin tinggi PH air maka mie yang dihasilkan tidak mudah patah karena absorbsi air meningkat dengan meningkatnya PH. Air yang digunakan harus air yang memenuhi persyaratan sebagai air minum, diantaranya tidak berwarna, tidak berbau dan tidak berasa Astawan, 2006).

Jumlah air yang ditambahkan pada umumnya sekitar 28-38\% dari campuran bahan yang akan digunakan. Jika lebih dari 38\% adonan akan menjadi sangat lengket dan jika kurang dari $28 \%$ adonan akan menjadi sangat rapuh sehingga sulit dicetak (Widyaningsih dan Murtini, 2006).

\subsubsection{Natrium Karbonat}

Berfungsi untuk mempercepat peningkatan gluten, meningkatkan elatisitas dan fleksibilitas mie, meningkatkan kehalusan tekstur, serta meningkatkan sifat kenyal. Bahan ini dapat diperoleh di toko-toko bahan kimia (Astawan, 2006).

Sunaryo (1985) menyatakan bahwa natrium karbonat dan garam fosfat telah sejak dahulu dipakai sebagai alkali untuk pembuatan mie. Komponen tersebut berfungsi untuk mempercepat pengikatan gluten, meningkatkan elastisitas 
dan fleksibilitas dan meningkatkan kehalusan tekstur pada mie basah yang dihasilkan..

Natrium karbonat $\left(\mathrm{Na}_{2} \mathrm{CO}_{3}\right)$ atau kalium polifosfat $\left(\mathrm{KH}_{2} \mathrm{PO}_{4}\right)$ berfungsi untuk meningkatkan $\mathrm{pH}$, menyebabkan warna sedikit kuning dengan flavor yang lebih baik. Secara khusus, natrium karbonat lebih berperan untuk kehalusan tekstur, kalium karbonat untuk meningkatkan elastisitas sedangkan kalium polifosfat untuk meningkatkan elastisitas dan fleksibilitas mie (Badrudin, 1994). Pada Tabel 4 terlihat batas maksimum penggunaan bahan tambah pangan menurut SNI dan Standar Codex. 
Tabel 4. Batas Maksimum Penggunaan BTP pada Formula Bayi Menurut SNI dan Standar Codex (BSN 1995 dan Codex Alimentarius 2007).

\begin{tabular}{|c|c|c|c|c|}
\hline No & Jenis BTP & Standar & $\begin{array}{l}\text { Batas Maksimum } \\
\text { (g/100 ml produk } \\
\text { siapkomsumsi) }\end{array}$ & $\begin{array}{c}\text { Jenis } \\
\text { formula bayi }\end{array}$ \\
\hline & Pengatur $\mathrm{pH}$ & & & \\
\hline 1 & $\begin{array}{l}\text { Natrium } \\
\text { Bikarbonat }\end{array}$ & $\begin{array}{c}\text { SNI 01-3955- } \\
1995\end{array}$ & $\begin{array}{c}\text { Secukupnya } \\
\text { dengan batas } \mathrm{Na} \\
\text { dan } \mathrm{K} \text { yang sesuai }\end{array}$ & $\begin{array}{l}\text { Seluruh jenis } \\
\text { formula }\end{array}$ \\
\hline \multirow[t]{2}{*}{2} & $\begin{array}{l}\text { Natrium } \\
\text { Karbonat }\end{array}$ & $\begin{array}{c}\text { SNI 01-3955- } \\
1995\end{array}$ & $\begin{array}{c}\text { Secukupnya } \\
\text { dengan batas } \mathrm{Na} \\
\text { dan K yang sesuai }\end{array}$ & $\begin{array}{l}\text { Seluruh jenis } \\
\text { formula }\end{array}$ \\
\hline & & $\begin{array}{c}\text { Standar Codex } \\
72-2007\end{array}$ & $\begin{array}{c}0,2 \text { dan dengan } \\
\text { batas } \mathrm{Na} \text { dan } \mathrm{K} \\
\text { yang sesuai }\end{array}$ & $\begin{array}{l}\text { Seluruh jenis } \\
\text { formula }\end{array}$ \\
\hline \multirow[t]{2}{*}{3} & $\begin{array}{l}\text { Natrium } \\
\text { Hidroksida }\end{array}$ & $\begin{array}{c}\text { SNI 01-3955- } \\
1995\end{array}$ & $\begin{array}{c}\text { Secukupnya } \\
\text { dengan batas } \mathrm{Na} \\
\text { danm K yang } \\
\text { sesuai }\end{array}$ & $\begin{array}{l}\text { Seluruh jenis } \\
\text { formula }\end{array}$ \\
\hline & & $\begin{array}{c}\text { Standar Codex } \\
72-2007\end{array}$ & $\begin{array}{c}0,2 \text { dan dengan } \\
\text { batas } \mathrm{Na} \text { dan } \mathrm{K} \\
\text { yang sesuai }\end{array}$ & $\begin{array}{l}\text { Seluruh jenis } \\
\text { formula }\end{array}$ \\
\hline 4 & $\begin{array}{l}\text { Natrium } \\
\text { Hydrogen } \\
\text { Karbonat } \\
\end{array}$ & $\begin{array}{c}\text { Standar Codex } \\
72-2007\end{array}$ & $\begin{array}{c}0,2 \text { dan dengan } \\
\text { batas } \mathrm{Na} \text { dan } \mathrm{K} \\
\text { yang sesuai }\end{array}$ & $\begin{array}{l}\text { Seluruh jenis } \\
\text { formula }\end{array}$ \\
\hline 5 & $\begin{array}{c}\text { Kalium } \\
\text { Bikarbonat }\end{array}$ & $\begin{array}{c}\text { SNI 01-3955- } \\
1995\end{array}$ & $\begin{array}{c}\text { Secukupnya } \\
\text { dengan batas } \mathrm{Na} \\
\text { dan K yang sesuai }\end{array}$ & $\begin{array}{l}\text { Seluruh jenis } \\
\text { formula }\end{array}$ \\
\hline 6 & Kalium Karbonat & $\begin{array}{c}\text { SNI 01-3955- } \\
1995\end{array}$ & $\begin{array}{c}\text { Secukupnya } \\
\text { dengan batas } \mathrm{Na} \\
\text { dan K yang sesuai }\end{array}$ & $\begin{array}{l}\text { Seluruh jenis } \\
\text { formula }\end{array}$ \\
\hline
\end{tabular}




\section{METODOLOGI PENELITIAN}

\subsection{Tempat dan Waktu}

Penelitian ini telah dilakukan di Laboratorium Teknologi Pangan Fakultas Pertanian Universitas Islam Indragiri. Telah dilakukan penelitian pada bulan Februari s/d Maret 2013.

\subsection{Bahan dan Alat}

\subsubsection{Bahan}

Bahan yang digunakan dalam penelitian ini adalah labu kuning (Cucurbita moschata), tepung terigu, garam, telur dan air. $\mathrm{Na}_{2} \mathrm{Co}_{3}, \mathrm{~K}_{2} \mathrm{SO}_{4}$, Aquadest, $\mathrm{NaOH} 0,2 \mathrm{~N}$.

\subsubsection{Alat}

Alat yang digunakan dalam penelitian ini adalah oven, timbangan, aluminium foil, beaker glass, Labu Kjeldhal, gelas ukur pipet tetes, desikator, erlenmeyer, mafel.

\subsection{Metoda Penelitian}

Penelitian dilakukan dengan menggunakan Rancangan Acak Lengkap (RAL) faktorial dengan dua faktor, yang terdiri dari :

Faktor I (A) : perbandingan tepung terigu dengan bubur labu kuning, yang terdiri dari beberapa taraf yaitu :

$$
\mathrm{A}_{1}=\text { Tanpa penambahan bubur labu kuning (100 g tepung terigu) }
$$


$\mathrm{A}_{2}=$ Tepung terigu $85 \%$ : bubur labu kuning $15 \%$ (85 g tepung terigu : $15 \mathrm{~g}$ labu kuning)

$\mathrm{A}_{3}=$ Tepung terigu $70 \%$ : bubur labu kuning $30 \%$ (70 g tepung terigu : $30 \mathrm{~g}$ labu kuning)

$\mathrm{A}_{4}=$ Tepung terigu $55 \%$ : bubur labu kuning $45 \%$ (55 g tepung terigu : $45 \mathrm{~g}$ labu kuning)

Total bahan baku yang digunakan didalam pengolahan mie basah dengan bahan baku tepung terigu yang disubtitusi dengan bubur labu adalah $100 \%$ (100 g).

Faktor II (B) : Jumlah natrium karbonat

$$
\begin{aligned}
& \mathrm{B}_{1}=0,10 \mathrm{~g} / 100 \mathrm{ml} \\
& \mathrm{B}_{2}=0,15 \mathrm{~g} / 100 \mathrm{ml} \\
& \mathrm{B}_{3}=\quad 0,20 \mathrm{~g} / 100 \mathrm{ml}
\end{aligned}
$$

Perlakuan di ulang sebanyak tiga kali sehingga di dapat pola perlakuan 4 X 3 X 3 terdapat 36 unit perlakuan.(N) Kombinasi perlakuan dapat dilihat pada tabel 5.

Tabel 5. Kombinasi perlakuan

\begin{tabular}{|c|c|c|c|c|}
\hline \multirow{2}{*}{$\begin{array}{c}\text { Jumlah Natrium } \\
\text { karbonat(B) }\end{array}$} & \multicolumn{4}{|c|}{ Perbandingan Tepung Terigu : Bubur Labu Kuning (A) } \\
\cline { 2 - 5 } & $\mathrm{A}_{1}$ & $\mathrm{~A}_{2}$ & $\mathrm{~A}_{3}$ & $\mathrm{~A}_{4}$ \\
\hline \multirow{2}{*}{$\mathrm{B}_{1}$} & $\mathrm{~A}_{1} \mathrm{~B}_{1}$ & $\mathrm{~A}_{2} \mathrm{~B}_{1}$ & $\mathrm{~A}_{3} \mathrm{~B}_{1}$ & $\mathrm{~A}_{4} \mathrm{~B}_{1}$ \\
& $(3 \mathrm{X})$ & $(3 \mathrm{X})$ & $(3 \mathrm{X})$ & $(3 \mathrm{X})$ \\
\hline \multirow{2}{*}{$\mathrm{B}_{2}$} & $\mathrm{~A}_{1} \mathrm{~B}_{2}$ & $\mathrm{~A}_{2} \mathrm{~B}_{2}$ & $\mathrm{~A}_{3} \mathrm{~B}_{2}$ & $\mathrm{~A}_{4} \mathrm{~B}_{2}$ \\
& $(3 \mathrm{X})$ & $(3 \mathrm{X})$ & $(3 \mathrm{X})$ & $(3 \mathrm{X})$ \\
\hline \multirow{2}{*}{$\mathrm{B}_{3}$} & $\mathrm{~A}_{1} \mathrm{~B}_{3}$ & $\mathrm{~A}_{2} \mathrm{~B}_{3}$ & $\mathrm{~A}_{3} \mathrm{~B}_{3}$ & $\mathrm{~A}_{4} \mathrm{~B}_{3}$ \\
& $(3 \mathrm{X})$ & $(3 \mathrm{X})$ & $(3 \mathrm{X})$ & $(3 \mathrm{X})$ \\
\hline
\end{tabular}


Data yang diperoleh dari setiap perlakuan di analisis secara statistik menggunakan program Statistik 8. Apabila hasil yang diperoleh berbeda nyata atau F. hitung lebih besar dari F tabel maka dilakukan uji lanjut dengan metode Beda Nyata Jujur (BNJ) pada taraf nyata 5\%.

Rancangan yang digunakan adalah rancangan acak lengkap (RAL) dua faktorial dengan model sebagai berikut :

$Y i j k=\mu+\alpha i+\beta j+(\alpha \beta)_{i j}+\varepsilon_{i j k}$

Dimana :

Yijk : Hasil pengamatan dari faktor A pada taraf ke-I dan faktor B pada taraf ke-j dengan ulangan $\mathrm{N}$

$\boldsymbol{\mu} \quad$ : Efek nilai tengah

$\boldsymbol{\alpha}_{\mathrm{i}} \quad$ : Efek faktor A pada taraf ke-i

Bj : Efek faktor B pada taraf ke-j

$(\boldsymbol{\alpha} \boldsymbol{\beta})_{\mathrm{ij}}$ : Efek interaksi dari faktor A pada taraf ke-I dan faktor B pada taraf ke-j

$\varepsilon_{\mathrm{ijk}} \quad$ : Efek galat dari faktor A pada taraf ke-I dan faktor B pada taraf ke-j dalam ulangan $\mathrm{N}$

\subsection{Pelaksanaan Penelitian}

\subsubsection{Pembuatan Bubur Labu kuning}

Langkah-langkah didalam pengolahan bubur labu kuning adalah sebagai berikut :

1. Sortasi

Sortasi bertujuan untuk memeilih labu yang berkualitas, dimana labu yang 
digunakan dalam kondisi sudah matang yaitu dengan melihat warna kulit labu kuning.

2. Pengupasan

Pengupasan bertujuan untuk memisahkan antara kulit buah dan daging buah labu.

3. Pemotongan,

Pemotongan bertujuan untuk mengecilkan ukuran supaya pada waktu penggilingan daya kerja mesin penggiling lebih mudah. Ditimbang 100 gr labu kuning, lalu dibersihkan dan dicuci.

4. Penggilingan (blender)

Penggilingan (blender) bertujuan untuk menghaluskan labu, agar mempermudah dalam pencampuran.

5. Bubur labu kuning.

Diagram alir proses pengolahan bubur labu kuning dapatr dilihat pada lampiran 2.

\subsubsection{Pembuatan Mie dengan Penambahan Labu kuning}

1. Pencampuran.

Tepung terigu, lalu dicampur dengan bubur labu kuning sesuai dengan perlakuan $(0 \%, 15 \%, 30 \%$, dan $45 \%)$. Ditambahkan garam dapur $(2 \%)$, telur (18 \%), air dan air (20\%). Ditambahkan natrium karbonat sesuai perlakuan $(0,10$ $\%, 0,15 \%, 0,20 \%)$.

2. Pengadonan.

Pengulenan adonan selama 20 menit sampai kalis. 
3. Pembentukan lembaran

Pembentukan lembaran adonan yang dilakukan berulang kali sebanyak tiga kali hingga memiliki ketebalan 1,5-2 mm.

4. Pencetakan

Proses pencetakan mie menggunakan pencetak mie (roll press), berfungsi untuk menipiskan lembaran dan rol kedua berfungsi mencetak mie.

5. Perebusan

Dilakukan perebusan selama 2 menit, jangan terlalu lama karena menyebabkan mie menjadi lembek, lalu diangkat dan didinginkan

6. Pendinginan.

Pendinginan. Ditambahkan minyak goreng agar antar lembaran mie tidak lengket.

7. Mie basah

Mie basah adalah mie yang mengalami proses perebusan setelah tahap pemotongan dan sebelum dipasarkan.

\subsection{Pengamatan}

\subsubsection{Kadar air (Dengan Metode Oven) (Sudarmadji, et al., 1989)}

1. Contoh dihaluskan dan ditimbang sebanyak $2 \mathrm{~g}$ dalam aluminium foil yang telah diketahui beratnya.

2. Kemudian dikeringkan dalam oven pda suhu $105^{\circ} \mathrm{C}$ selama 4 jam.

3. Kemudian didinginkan di dalam desikator selama 15 menit dan ditimbang.

4. Selanjutnya dipanaskan kembali selama 30 menit, didinginkan kembali didalam 
desikator dan ditimbang.

5. Perlakuan ini diulangi sampai tercapai berat konstan.

perhitungan :

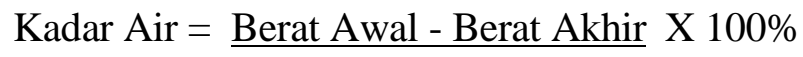

Berat Awal

\subsubsection{Kadar Protein (Sudarmadji, et al., 1989)}

1. Diambil contoh sebanyak $2 \mathrm{~g}$ dan dimasukkan ke dalam tabung dekstruksi. Ditimbang 2 g campuran $\mathrm{CuSO}_{4} .5 \mathrm{H}_{2} \mathrm{SO}_{4}$ dan $\mathrm{K}_{2} \mathrm{SO}_{4}$ dicampurkan ke dalam bahan, lalu ditambahkan $\mathrm{H}_{2} \mathrm{SO}_{4}$ pekat sebanyak $5 \mathrm{ml}$. Didestruksi hingga menjadi cairan berwarna jernih kemudian dibiarkan hingga dingin. Hasil destruksi dibilas dengan aquadest sebanyak $10 \mathrm{ml}$ dan ditampung di labu suling.

2. Ditambahkan larutan $10 \mathrm{ml} \mathrm{NaOH} 15 \%$ hingga terbentuk warna merah jingga kemudian didestilasi. Hasil penyulingan ditampung dalam erlenmeyer yang berisi $25 \mathrm{ml} \mathrm{H}_{3} \mathrm{BO}_{3} 3 \%$, kemudian ditampung hingga $200 \mathrm{ml}$.

3. Hasil sulingan dititrasi dengan $\mathrm{HCl} 0,1014 \mathrm{~N}$ hingga terbentuk warna merah muda. Dibuat juga larutan blanko dengan mengganti bahan dengan aquadest, dilakukan destruksi, destilasi, dan titrasi seperti pada bahan contoh.

Perhitungan

$$
\begin{aligned}
& \% \mathrm{~N}=\frac{(m l \mathrm{HCl}-\mathrm{ml} \text { blanko }) \times \text { Normalitas } \times 14.007 \times 100}{m g \text { sampel }} \\
& \% \text { protein }=\% \mathrm{~N} \times \text { faktor konversi }
\end{aligned}
$$


3.5.3 Kadar Abu (Sudarmadji, et al., 1984).

1. Ditimbang bahan sebanyak $5 \mathrm{~g}$ lalu dikeringkan

2. Bahan yang telah kering dimasukkan dalam krus porselin yang kering yang telah diketahui beratnya.

3. Kemudian dimasukkan dalam mafel sampai diperoleh abu berwarna keputih-putihan.

4. Kemudian dikeluarkan dan kurs dimasukkan ke dalam desikator dan ditimbang berat abu setelah dingin.

Perhitungan :

$\%$ Kadar Abu $=\frac{\text { berat akhir }}{\text { berat awal }} \times 100 \%$

\subsubsection{Uji Organoleptik (Soekarto, 1985)}

Uji organoleptik tekstur (kekenyalan), warna, aroma dan tekstur dilakukan dengan uji kesukaan atau uji hedonik. Sampel berupa mie yang sudah dimasak diberikan kepada panelis sebanyak 20 orang (tidak terlatih) dengan kode tertentu. Parameter yang diamati adalah tekstur (kekenyalan), warna dan aroma dari mie yang dihasilkan. Formulir uji organoleptik dapat di lihat pada lampiran 4. 


\section{KESIMPULAN DAN SARAN}

\subsection{Kesimpulan}

1. Pengaruh Perbandingan Tepung Terigu dengan Labu Kuning dan Penambahan Natrium Karbonat terhadap Mutu Mie Basah yang di hasilkan, memberikan pengaruh nyata menurut uji BNJ pada taraf $5 \%$ mie basah yang dihasilkan, dengan nilai perlakuan yang terbaik untuk kadar air ( A4B3) $76.89 \%$, kadar protein (A1B3) $14.97 \%$, kadar abu (A1B1) $1.51 \%$, dan untuk uji organoleptik perlakuan terbaiknya untuk warna pada perlakuan (A4B3) yaitu 3.08, aroma pada perlakuan (A3B2) yaitu 3.08 dan tekstur pada pelakuan (A2B3) yaitu 3.07 .

2. Pengaruh perbandingan tepung terigu dengan labu kuning dan penambahan natrium karbonat terhadap mutu mie basah yang di hasilkan, perlakuan terbaik dari (A1B3) dengan jumlah kadar air $70.83 \%$, kadar protein $14.97 \%$, kadar abu $1.50 \%$, warna 3.06 , aroma 3.02 dan tekstur 3.06.

\subsection{Saran}

3. Perlu dilakukan penelitian mengenai lama penyimpanan mie basah dengan menggunakan natrium karbonat pada suhu kamar.

4. Untuk mengetahui mutu mie basah yang baik, maka perlu menurunkan jumlah bubur labu kuning. 


\section{DAFTAR PUSTAKA}

Anonim. 2010. Labu. http://id.Wikipedia.org/wiki/labu.htm. Akses Tanggal 5 Februari 2013, Makassar.

Anonim. 2010. Labu Kuning. http://endrah.blogspot.com. Akses Tanggal 5 Februari 2013, Makassar.

Anonim. 2010. Hidangan Dari Labu Kuning. Akses Tanggal 5 Februari 2013, Makassar.

Almentarius, BSN. 2007. Batas Maksimum Penggunaan BTP Pada Formula Bayi. Bogor.

Astawan, M. 2006. Membuat Mie dan Bihun. Penebar Swadaya, Jakarta.

Bangun, M.K. 2001. Perancangan Percobaan. Fakultas Pertanian USU, Medan.

Cahyono, B. 2002. Labu kuning. Kanisius, Yogyakata.

Departemen Kesehatan, R.I. 1992. Daftar Komposisi Bahan Makanan. Bhratara Karya Aksara, Jakarta.

Desrosier, N.W. 1988. Teknologi Pengawetan Pangan. Penerjemah M.Muljohardjo. UI-Press, Jakarta.

Kumalaningsih, S. 2006. Antioksidan Alami Penangkal Radikal Bebas. Trubus Agisarana, Surabaya.

Irianto dan Mulono Apriyanto, (2012). Analisa Mutu Minyak Kelapa Sawit Mentah Di POM IV NYATO PT. TH INDO PLANTATIONS Kecamatan Pelangiran Kabupaten Indragiri Hilir Riau, Jurnal Teknologi Pertanian, $1(2): 47-56$

Robsons, J. 1976. Some Introductory Thoughts on Intermediate Moisture Foods. I dalam Davies, K., G.G. Birch and K.J. Parker. Intermediate Moisture Food. Applied Science Publ, Ltd, London.

Setianingrum, A.W. dan Marsono. 1999. Pengkayaan Vitamin A dan Vitamin E dalam Pembuatan Mie Instan Menggunakan Minyak Sawit Merah. Kumpulan Penelitian Terbaik Bogasari 1998-2001, Jakarta.

Soekarto. 1985. Penilaian Organoleptik. Pusat Pengembangan Teknologi Pangan. IPB, Bogor.

Sudarmadji, S. B. Haryono dan Suhardi, 1997. Analisa Bahan Makanan dan Hasil 
Pertanian. Liberty, Yogyakarta.

Sudarto, Yudo., 1993. Budidaya Labu Kuning. Kanisius. Yogyakarta.

Sunaryo, E. 1985. Pengolahan Produk Serealia dan Biji-bijian. Fateta-IPB, Bogor.

Widyaningsih, T.B. dan E.S. Murtini. 2006. Alternatif Pengganti Formalin Pada Produk Pangan. Trubus Agrisarana, Surabaya. 
Lampiran 2. Skema pembuatan bubur labu kuning

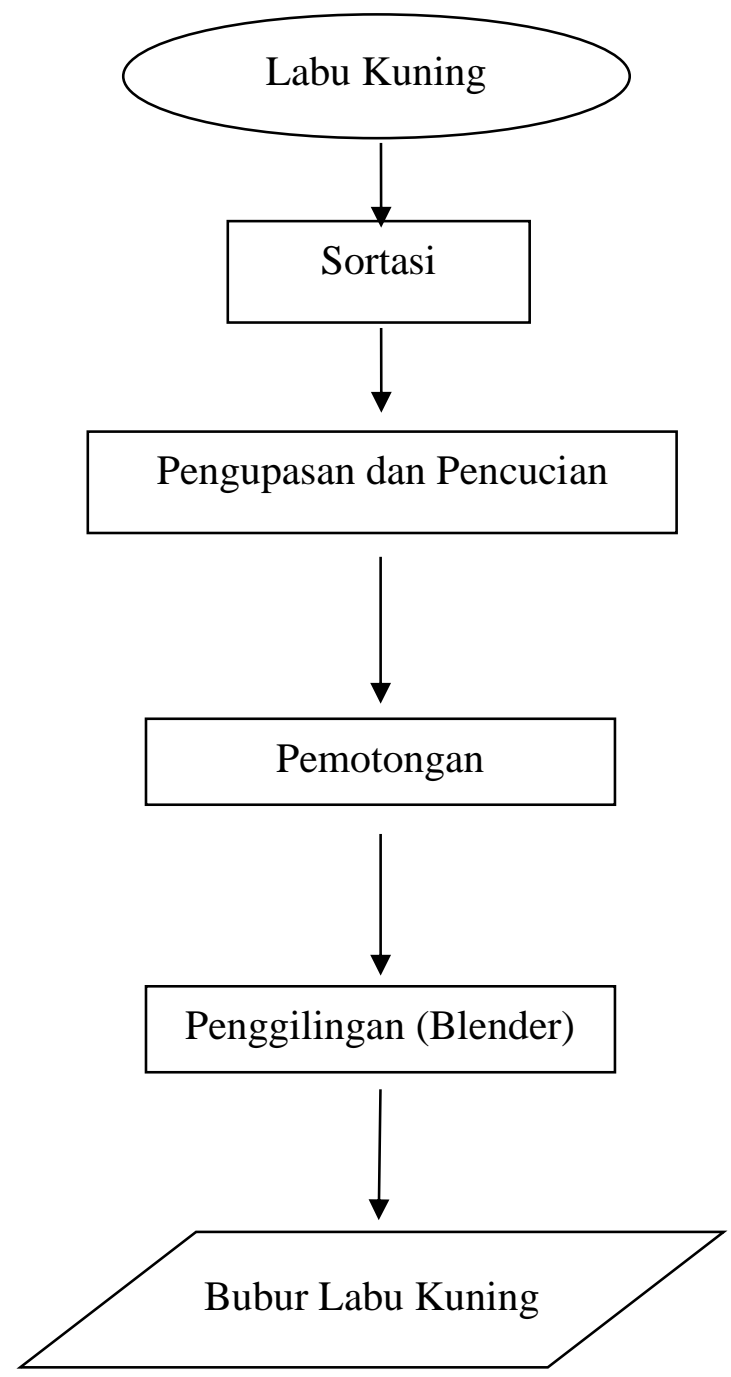


Lampiran 3. Skema Pembuatan Mie Basah Dengan Penambahan Bubur Labu kuning

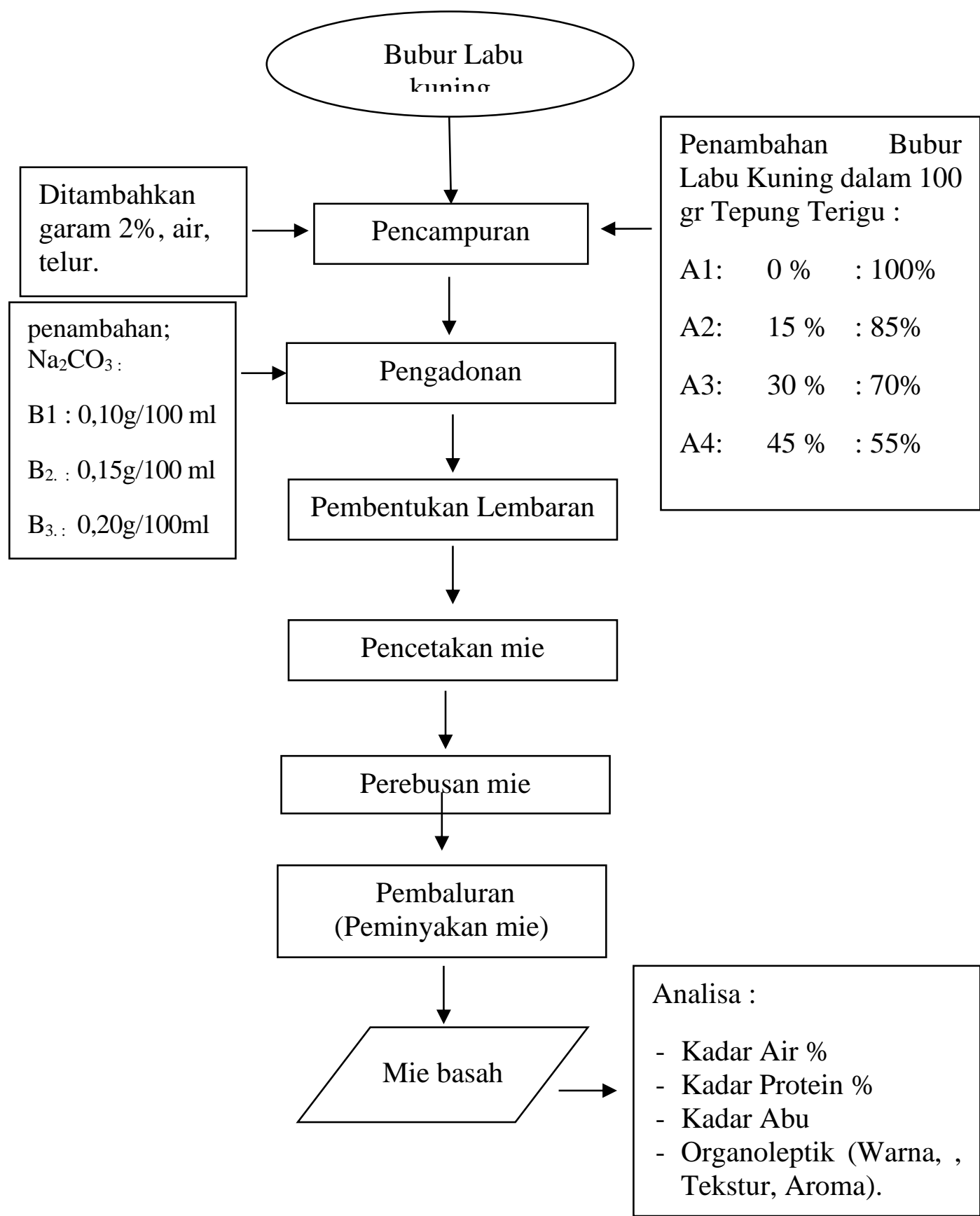


Lampiran 4. Formulir Uji Organoleptik

No. penguji :

Nama

Bahan yang diuji :

Tanggal

\begin{tabular}{|l|c|l|c|c|c|}
\hline \multirow{2}{*}{ Spesifikasi } & \multirow{2}{*}{ Skor } & \multicolumn{4}{c|}{ Kode contoh } \\
\cline { 4 - 6 } & & A & B & C & D \\
\hline 1. Warna & & & & & \\
\hline $\begin{array}{l}\text { Sangat suka (putih } \\
\text { kekuningan) }\end{array}$ & $\mathbf{5}$ & & & & \\
\hline Suka (kuning) & $\mathbf{4}$ & & & & \\
\hline Biasa (kuning kecoklatan) & $\mathbf{3}$ & & & & \\
\hline Kurang suka (Coklat muda) & $\mathbf{2}$ & & & & \\
\hline Tidak suka (agak coklat) & $\mathbf{1}$ & & & & \\
\hline 2. Aroma & & & & & \\
\hline Sangat suka (sgt khas) & $\mathbf{5}$ & & & & \\
\hline Suka (khas) & $\mathbf{4}$ & & & & \\
\hline Biasa (normal) & $\mathbf{3}$ & & & & \\
\hline Kurang suka (kurang khas) & $\mathbf{2}$ & & & & \\
\hline Tidak suka (tdk khas) & $\mathbf{1}$ & & & & \\
\hline 3. Tekstur & & & & & \\
\hline Sangat suka (kering \&halus) & $\mathbf{5}$ & & & & \\
\hline Suka (agak kering \& halus) & $\mathbf{4}$ & & & & \\
\hline Biasa & $\mathbf{3}$ & & & & \\
\hline Kurang suka & $\mathbf{2}$ & & & & \\
\hline Tidak suka & $\mathbf{1}$ & & & & \\
\hline 4. Rasa & & & & & \\
\hline Sangat suka & $\mathbf{5}$ & & & & \\
\hline Suka & $\mathbf{4}$ & & & & \\
\hline Biasa & $\mathbf{2}$ & & & & \\
\hline Kurang suka & & & & & \\
\hline Tidak suka & & & & \\
\hline
\end{tabular}

